\title{
Brown Bead of Broccoli. I. Response of the Physiological Disorder to Management Practices
}

\author{
Sylvie Jenni ${ }^{1}$ \\ Agriculture and Agri-Food Canada, Horticultural Research and Development \\ Centre, Saint-Jean-sur-Richelieu, QC, J3B 3E6, Canada
}

Pierre Dutilleul $^{2}$ and Stephen Yamasaki ${ }^{3}$

Macdonald Campus of McGill University, 21111 Lakeshore Road, SainteAnne-de-Bellevue, QC, H9X 3V9, Canada

Nicolas Tremblay ${ }^{4}$

Agriculture and Agri-Food Canada, Horticultural Research and Development Centre, Saint-Jean-sur-Richelieu, QC, J3B 3E6, Canada

Additional index words. brown bead, Brassica oleracea, browning, nitrogen, soil type

Abstract. To investigate whether brown bead can be reduced by various cultural practices, a 3-year field study was conducted on a 600-acre broccoli (Brassica oleracea L., Italica group) farm in southwestern Quebec. Factors studied included N fertilization, soil series, previous crop, season of bed forming, or planting method. Four $\mathbf{N}$ treatments were randomly applied to two blocks in 41 fields of 'Everest' broccoli: 85-0-0, 85-54-0, 85-5454, and 85-54-108; the first number indicating $N\left(\mathrm{~kg}^{\circ} \mathrm{ha}^{-1}\right)$ applied before planting; the second, $N$ applied 5 weeks after planting; and the last, $N$ applied 7 weeks after planting. Over the 3-year study, brown bead affected $11 \%$ of the broccoli heads and accounted for one-third of the rejects. Brown bead severity on individual heads was described on a 0-8 scale. Plots with greater $N$ applications (i.e., 85-54-54, 85-54-108) had significantly $(P<$ 0.001) lower proportions of plants with brown bead compared with plots with lower $\mathrm{N}$ applications. Brown bead incidence reacted similarly from year to year to $\mathbf{N}$ fertilization and soil type. However, fertilization interacted with soil type. The less $\mathbf{N}$ was applied, the more soil effect was important. Soil effect was maximum at a low $\mathrm{N}$ level (85-0-0) with 2.5 times more plants showing brown bead in the Saint Blaise series than in the Sainte Rosalie series. Bed type, previous crop, or planting type did not affect the incidence of brown bead.

Brown bead (also called brown bud) in broccoli is a poorly documented physiological disorder. The disorder was first reported after farmers noticed its occurrence in California and Mexico, particularly during warm summers (Flint, 1985). Although brown bead is now sporadic and not of significant importance in California, the disorder has been reported in Spain (Maroto et al., 1993), and Canada(Hildebrand, 1994). For broccoli growers of southwestern Quebec, it represents one

Received for publication 25 Oct. 2000. Accepted for publication 14 Apr. 2001. Agriculture and AgriFood Canada, Saint-Jean-sur-Richelieu (Que.), Contribution no. 335/2001.03.01R. The authors would like to thank François Cousineau of Les Fermes Paul Cousineau et Fils, and the Matching Investment Initiative (MII) Program of Agriculture and AgriFood Canada for their financial support, as well as Julie Nichols, Gaston Mercier, Nathalie Leboeuf, and Jean-François Dubuc for their technical assistance.

${ }^{1}$ Researcher; to whom reprint requests should be addressed. E-mail address: jennis@em.agr.ca

${ }^{2}$ Associate Professor, Statistician, Dept. of Plant Science.

${ }^{3}$ Postdoctoral Fellow, Dept. des sciences biologiques, Université du Québec à Montréal, C.P. 8888, Succ. Centre-ville, Montréal, Qué, H3C 3P8, Canada. ${ }^{4}$ Researcher. of the major causes of rejects along with clubroot (Plasmodiophora brassicae W.).

Brown bead symptoms consist of a yellowing, followed by a tan or copper coloration of the unopened floral buds of broccoli as they approach marketable maturity (Fig. 1). Brown buds develop at or near the apical portions of the multiple branches of the primary inflorescence (Steta, 1987). As the disorder becomes more severe, it spreads through the inflorescence and the flower buds easily detach. The necrotic tissues often drop off and secondary infections of soft rotting bacteria (Erwinia and Pseudomonas sp.) may cause further damage (Hildebrand, 1994).

Certain cultivars are more susceptible to this preanthesis flower abortion; for example, $6 \%$ and $4 \%$ of 'Coaster' and 'Shogun' heads showed symptoms compared with $35 \%$ with 'Skiff' (Maroto et al., 1993). In California, rapid growth associated with temperatures above $25^{\circ} \mathrm{C}$ and low relative humidity tended to increase brown bead incidence (Steta, 1987). In Spain, the average maximum temperature during the $5 \mathrm{~d}$ preceding marketable maturity was highly correlated with the proportion of broccoli heads with brown bead (LopezGalarza et al., 1993). Close to $10 \%$ of broccoli heads got brown bead at temperatures under $30{ }^{\circ} \mathrm{C}$, and $>50 \%$ when temperatures were over $36{ }^{\circ} \mathrm{C}, 5 \mathrm{~d}$ prior to harvest. In Canada, periods of high temperature followed by abundant rainfall inducing rapid growth of broccoli were associated with brown bead (Hildebrand, 1994).

Brown bead has also been associated with low calcium levels in the rapidly growing head tissue of broccoli (Flint, 1985; Steta, 1987). Other studies have reported that broccoli showing brown bead had higher $\mathrm{Ca}$ and lower $\mathrm{K}$ content compared with healthy buds (Pascual et al., 1996). Foliar application of calcium chloride did not show consistent results in reducing brown bead damage (Maroto et al., 1993).

The objectives of this study were to: 1) quantify the importance of brown bead damage over three growing seasons; 2) describe the severity of brown bead symptoms and relate it to the incidence of the disorder; and 3) determine, under field conditions, whether cultural practices affect the incidence and severity of brown bead in broccoli.

\section{Materials and Methods}

Field layout. Thirteen experimental 'Everest' broccoli fields in 1997, 18 in 1998, and 10 in 1999 were selected at the 600-acre farm of Paul Cousineau and Sons (St-Constant, Que., lat. $45^{\circ} 22^{\prime} \mathrm{N}$, long. $73^{\circ} 37^{\prime} \mathrm{W}$ ). The date of planting or seeding as well as the soil type, previous crop, and bed type varied among experimental fields. There were eight fields in fine clayey silt Saint Blaise (orthic humic gleysol, fine clayey over loamy, mixed, neutral, alkaline, strongly calcareous, mild, and subaquic) and 33 fields in clay Sainte Rosalie (orthic humic gleysol, very fine clayey, mixed, neutral, mild, and subaquic.). Thirteen fields were grown in the previous crop year with corn (Zea mays L.), 12 fields with soybean

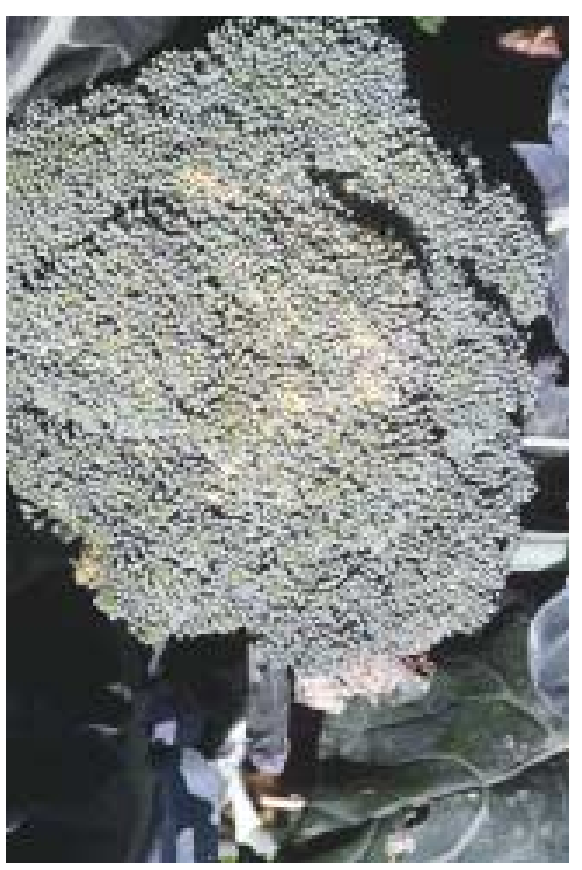

Fig. 1. Broccoli head with brown bead, a physiological disorder. 
[Glycine $\max$ (L.) Merr.], 11 fields with pea (Pisum sativum L.), and five with cereal. Beds were formed during the spring in nine fields and during the fall in the 32 others. In each experimental field, the four following $\mathrm{N}$ treatments were applied randomly to two blocks: 1) $\mathrm{N}$ at $85 \mathrm{~kg} \cdot \mathrm{ha}^{-1}$ applied before planting only $(85-0-0) ; 2) \mathrm{N}$ at $85 \mathrm{~kg} \cdot \mathrm{ha}^{-1}$ applied before planting, and $54 \mathrm{~kg} \cdot \mathrm{ha}^{-1} 5$ weeks after establishment (85-54-0); 3) $\mathrm{N}$ at $85 \mathrm{~kg} \cdot \mathrm{ha}^{-1}$ applied before planting; $54 \mathrm{~kg} \cdot \mathrm{ha}^{-1} 5$ weeks after establishment and $54 \mathrm{~kg} \cdot \mathrm{ha}^{-1} 7$ weeks after establishment (85-54-54); and 4) $\mathrm{N}$ at $85 \mathrm{~kg} \cdot \mathrm{ha}^{-1}$ applied before planting, $54 \mathrm{~kg} \cdot \mathrm{ha}^{-1} 5$ weeks after establishment, and $108 \mathrm{~kg} \cdot \mathrm{ha}^{-1} 7$ weeks after establishment (85-54-108). Phosphorus and potassium were prescribed according to soil tests. Weeds and insects were controlled according to local recommendations [Conseil des Productions Végétales du Québec (CPVQ), 1995]. Overhead irrigation was applied at seeding or planting and after emergence during dry periods.

Over the 3-year study, data were collected from 328 plots (41 experimental fields $\times 4 \mathrm{~N}$ fertilization levels $\times 2$ blocks), consisting of four 1 -m-wide beds $\times 5 \mathrm{~m}$ long. Each bed contained two rows of broccoli. Twenty-six broccoli experimental fields were direct-seeded between 14 May and 20 June 1997, 16 Apr. and 25 June 1998, and 7 May and 4 June 1999. They were all thinned to a density of $11.6 \pm$ 0.15 plants $/ \mathrm{m}^{2}$. Broccoli was also transplanted into 15 experimental fields between 18 and 21 May 1997, 30 Apr. and 24 July 1998, and 12 and 25 May 1999 at a density of $7.3 \pm 0.07$ plants $/ \mathrm{m}^{2}$. Broccoli heads were harvested between 17 July and 13 Sept. 1997, 30 June and 28 Sept. 1998, and 14 July and 23 Aug. 1999.

Measurement of brown bead symptoms. Measurements were made on four 4-m-long rows (two beds of two rows) of broccoli plants. The incidence of brown bead was expressed as the proportion of plants presenting the symptoms (BBP). The severity of symptoms was evaluated on each head at commercial maturity (Table 1). The number of brown florets $(\mathrm{F})$ was recorded if the symptoms were light $(\mathrm{F} \leq$ $10)$. If the number of brown florets was $>10$ and grouped in parts of the inflorescence, the area of the affected surface was evaluated $(G$, in $\left.\mathrm{cm}^{2}\right)$. When the symptoms were severe $(\mathrm{G}>$ $2 \mathrm{~cm}^{2}$ ), the proportion of the head surface area with brown bead symptoms was evaluated (S,

Table 1. Evaluation of brown bead severity in broccoli on a $0-8$ scale based on the number of brown individual florets $(\mathrm{F})$, the surface area $\left(\mathrm{in}^{2} \mathrm{~cm}^{2}\right.$ ) of groups of brown florets $(\mathrm{G})$, and the proportion of the head surface area showing symptoms (S).

\begin{tabular}{lc}
\hline $\begin{array}{l}\text { Severity index } \\
\text { of brown bead }\end{array}$ & Description of symptoms \\
\hline 0 & No symptom \\
1 & $\mathrm{~F} \leq 5$ \\
2 & $5<\mathrm{F} \leq 10$ \\
3 & $10<\mathrm{F}$ \\
4 & $\mathrm{G}<1$ \\
5 & $\mathrm{G}=1$ \\
6 & $1<\mathrm{G}$ or S $\leq 0.25$ \\
7 & $0.25<\mathrm{S} \leq 0.5$ \\
8 & $0.5<\mathrm{S}$ \\
\hline
\end{tabular}

from 0 to 1 ). An index of severity (from 0 to 8 ) was then evaluated for each head on the basis of these observations (Table 1). A value of brown bead severity was then calculated for each plot as the average index for the heads showing the symptoms only (BBI). Marketable heads were counted in each plot at commercial maturity, which is defined as the time when $50 \%$ of the heads reached $10 \mathrm{~cm}$ in diameter.

Statistical analyses. The arcsine transformation, $X^{\prime}=\arcsin \left(X^{0.5}\right)$, was applied to the BBP data because these were proportions (Sokal and Rohlf, 1995). Although the BBI data were basically ranks, these ranks were averaged over a large number of broccoli heads in each plot to yield the observations used for the variable in the analyses. The central limit theorem thus applies and the BBI variable can be analyzed with parametric methods (Sokal and Rohlf, 1995). Outliers were detected using the method of Tukey (1977), and removed following the method of Grubbs (1969).

In a preliminary step, Barlett's test for homoscedasticity (Sokal and Rohlf, 1995) was carried out, and both transformed BBP and raw BBI variables were found to have homogeneous variances among years. Therefore, the analysis of variance (ANOVA) was carried out on the pooled data of the 3 years. We first carried out the ANOVA with field and block (nested within field) in the model. These terms were consistently nonsignificant and were therefore dropped from the final analysis. The final model included only the terms for year, fertilization, and the interaction between the two. Since we considered the year factor to be random, the $\mathrm{N}$ fertilization main effects were tested against the year $\times \mathrm{N}$ fertilization interaction when this interaction was significant. For each $\mathrm{N}$ fertilization level separately, and for all levels combined, the effects of previous crop and planting vs. seeding were tested in an ANOVA model including the effects of soil and year and their interaction. Given the incompleteness of the factorial combinations, the effect of previous crop and planting vs. seeding were nested within the year $x$ soil interaction. All analyses of variance were carried out with the procedure GLM (SAS Institute, 1997), and the least-squares means were used in the mean separation with the Bonferroni correction (Steele et al., 1997).

\section{Results and Discussion}

Over the 3 years of the experiment, $7 \%$ to $17 \%$ of the heads were unmarketable because of brown bead symptoms, while $17 \%$ to $27 \%$ of the broccoli heads were rejected for other reasons, such as clubroot, small heads, or rot (Fig. 2). Brown bead damage was more important in 1999, which was a particularly hot and dry year (Fig. 3). During the period between 21 June and 7 Oct., the mean temperature was $17.6^{\circ} \mathrm{C}$ in $1997,18.5^{\circ} \mathrm{C}$ in 1998 , and $19^{\circ} \mathrm{C}$ in 1999 , with 869,778 , and $691 \mathrm{~mm}$ of rain for each year, respectively. In 1999, $17 \%$ of the broccoli heads were presenting brown bead symptoms, and $22 \%$ of the heads were rejected for other causes.

When a plot showed $<10 \%$ of broccoli heads with brown bead (Fig. 4), symptoms could range from light (index of 1) to severe (index of 8). As more heads were affected, the range of symptoms tended to narrow. In plots with $>20 \%$ of heads showing brown bead, $87 \%$ of these heads showed symptoms with an index of severity between 3 and 6. Similar tendencies were observed for each year. The lack of correlation between BBP and BBI justified the use of both variables to characterize brown bead. This lack of correlation was combined with an apparent decrease of the variance of severity with increasing value of incidence (Fig. 4).

In the absence of significant year $\times \mathrm{N}$ fertilization interaction, the effect of $\mathrm{N}$ fertilization on BBP and BBI was consistent among

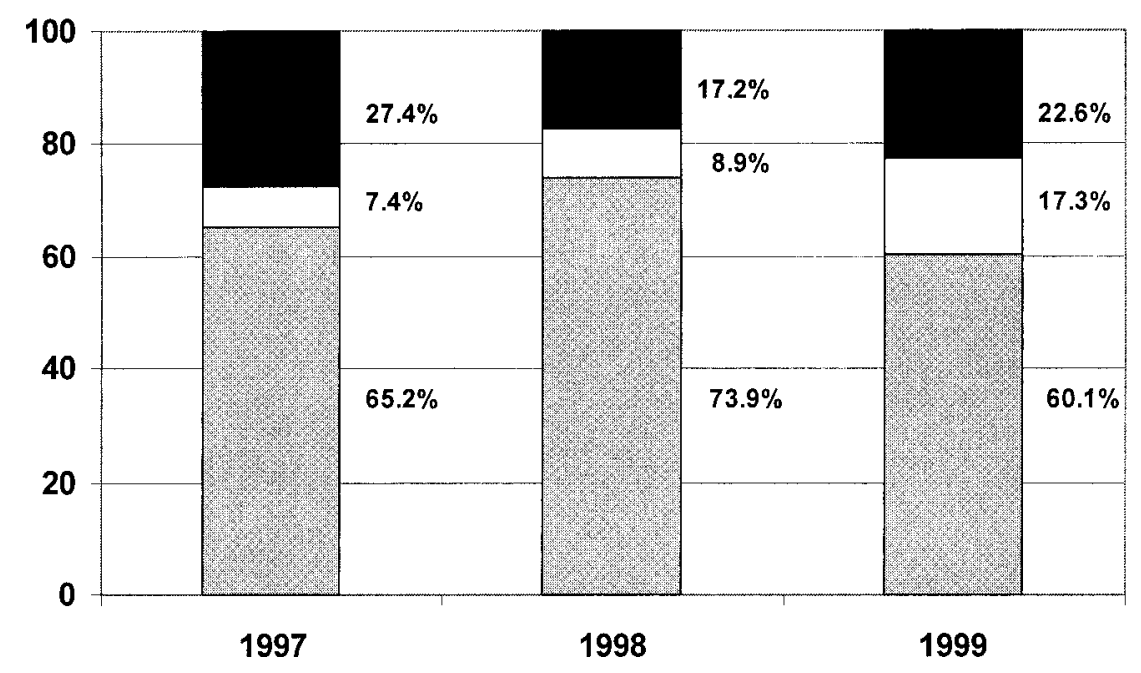

Marketable $\square$ Rejected for brown bead $\square$ Other rejects

Fig. 2. Percentage of marketable broccoli heads, heads presenting brown bead symptoms, and heads rejected for other reasons, such as rots, clubroot, or a diameter $<10 \mathrm{~cm}$. 

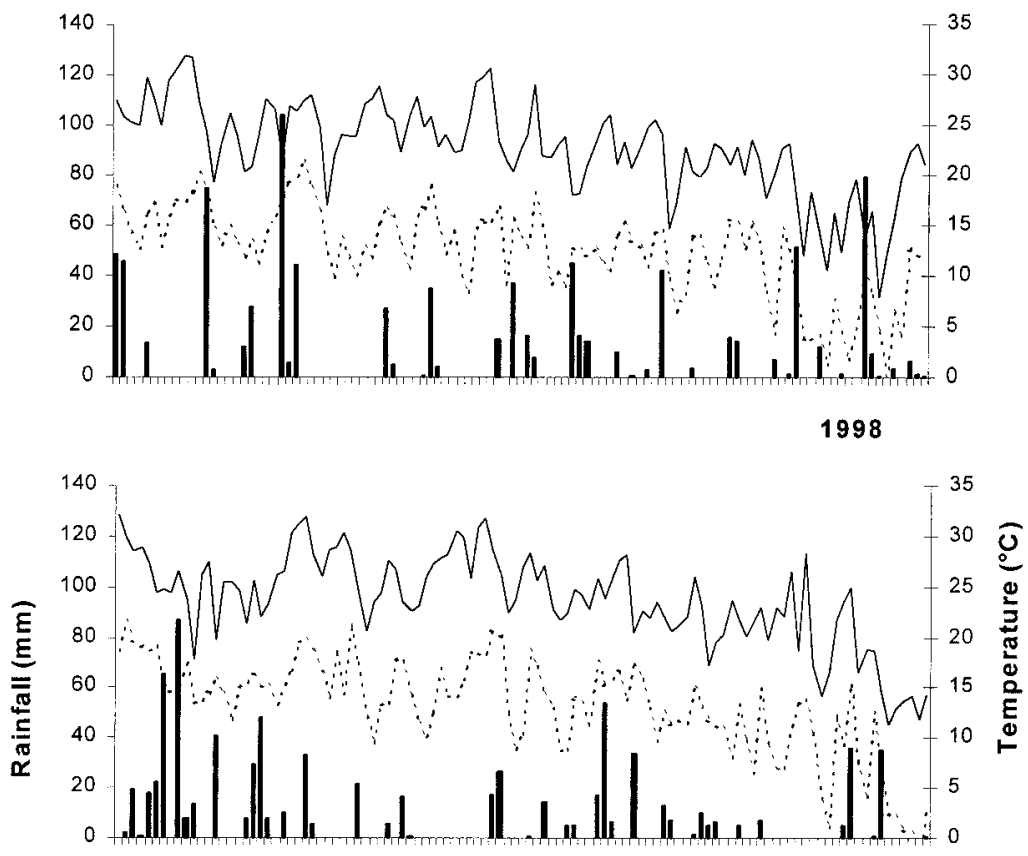

1999

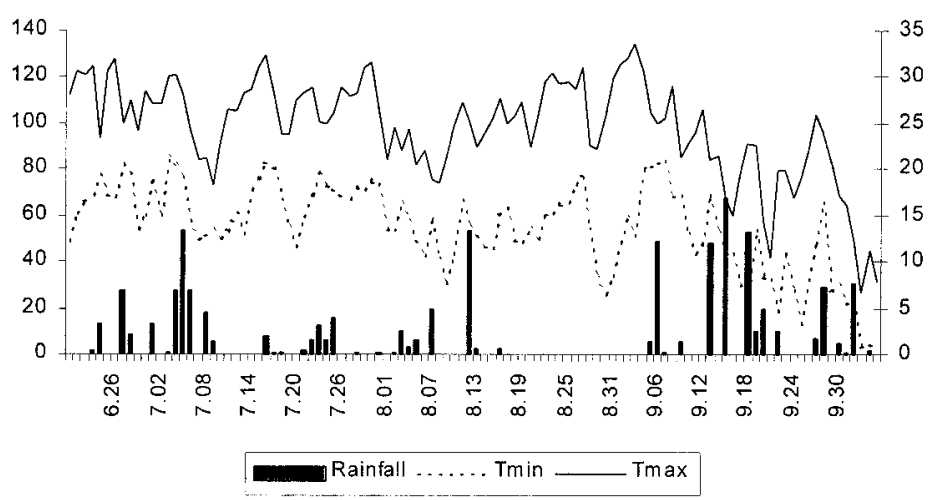

Fig. 3. Maximum temperature (Tmax), minimum temperatures (Tmin) and rainfall in Saint-Constant, Que.

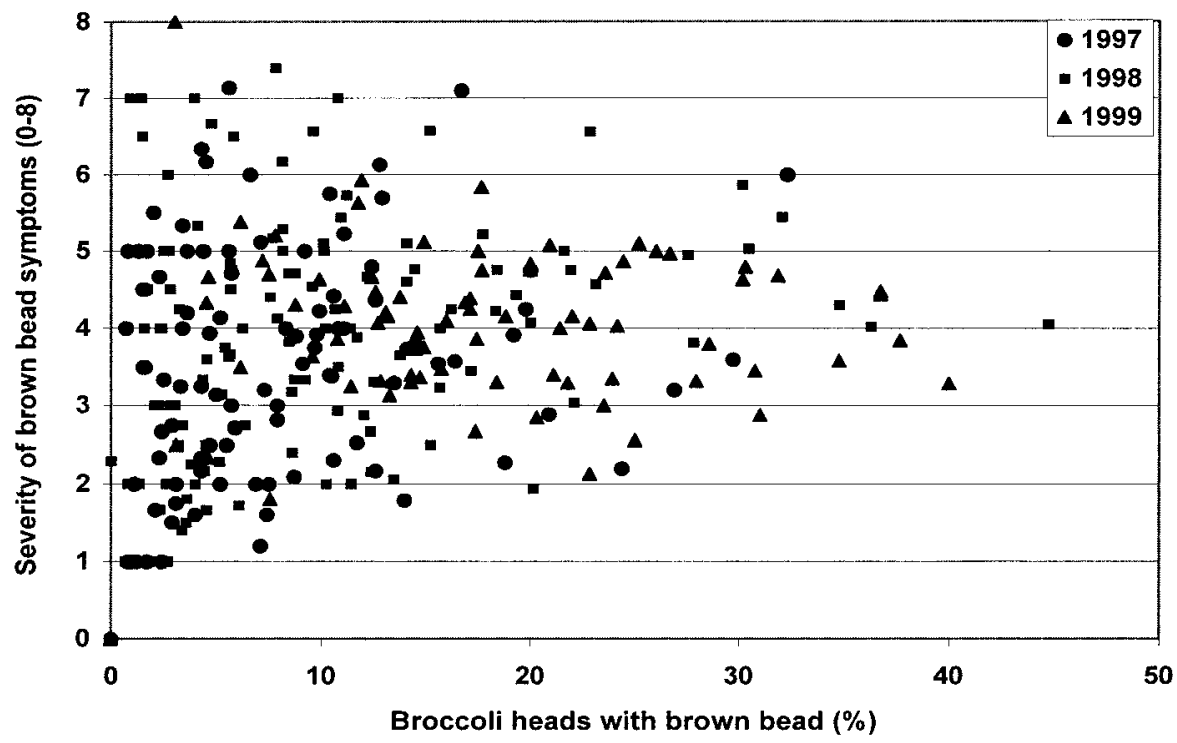

Fig. 4. Relationship between the percentage of broccoli heads affected by brown bead and the severity of symptoms on a $0-8$ scale $(0=$ no symptom; $8=$ very severe symptoms). The brown bead severity reported is an average index calculated over the heads affected by the symptoms. years (Table 2$)$. However, the incidence $(P=$ $0.0001)$ and severity $(P=0.0080)$ of brown bead significantly varied from year to year. Nitrogen fertilization had a significant effect on the proportion of heads with brown bead $(P$ $=0.0078)$, but not on the severity of symptoms. Fewer plants had brown bead with greater levels of $\mathrm{N}$ fertilization, especially with 85 54-54 and 85-54-108, compared with plots receiving $85-0-0$ or $85-54-0$ of $\mathrm{N}$. Those plots with more $\mathrm{N}$ fertilization also tended to have a greater number of marketable heads (Table 2). Twenty percent more marketable heads were obtained with the 85-54-108 N fertilization treatment compared with the 85 $0-0$ treatment. Although the effect of $\mathrm{N}$ on the severity of brown bead was not statistically significant, the average index of severity decreased from 3.87 to 3.30 as greater amounts of $\mathrm{N}$ were applied.

Whether the bed was formed in the previous fall or in the spring did not influence the presence or severity of brown bead symptoms in 1997 and 1998 (data not shown). Since only fall-formed beds were used in 1999, this factor was not included in the analysis covering the 3 years.

In the absence of significant year $\times$ soil interaction, the effect of soil series (i.e., Saint Blaise or Sainte Rosalie) on BBP and BBI was consistent from year to year (Table 3 ). The soil series had a significant effect on the proportion of plants with brown bead at low levels of $\mathrm{N}$ fertilization (i.e., 85-0-0 and 85-54-0) and at all levels combined. Over all $\mathrm{N}$ fertilization levels, there were twice as many plants with brown bead in the Saint Blaise series (13.3\%) as in the Sainte Rosalie series $(6.7 \%)$. The difference between the two soil series was even greater at low $\mathrm{N}$ levels. At $85-0-0 \mathrm{~N}$, the plots on the Saint Blaise series had a BBP of $17.9 \%$, compared with $7.4 \%$ in the Sainte Rosalie series. The severity of symptoms was similar in the two soil series at all $\mathrm{N}$ fertilization levels except the greatest $\mathrm{N}$ level (i.e., 8554-108), at which brown bead was less severe in the Sainte Rosalie series (index of 3.20), compared with the Saint Blaise series (index of 3.92). However, the number of marketable heads was similar in both soil series.

Table 2. Effects of $\mathrm{N}$ fertilization (fert.) and year on the incidence and severity of brown bead in broccoli and the number of marketable heads.

\begin{tabular}{lccc}
\hline \hline & $\begin{array}{c}\text { Heads with } \\
\text { brown bead } \\
(\%)\end{array}$ & $\begin{array}{c}\text { Severity } \\
\text { index } \\
(0-8)\end{array}$ & $\begin{array}{c}\text { Marketable } \\
\text { heads } \\
\left(\text { no }^{-2}\right)\end{array}$ \\
\hline & & p-value \\
Model 1 & & & \\
Year (Y) & 0.0001 & 0.0080 & 0.0001 \\
Fert. (F) & 0.0078 & 0.1545 & 0.0193 \\
Y $\times$ F & 0.7092 & 0.9589 & 0.9962 \\
& & LS means \\
& & \\
$85-0-0$ & $10.75 \mathrm{c}^{\mathrm{y}}$ & $3.87 \mathrm{a}$ & $6.17 \mathrm{a}$ \\
$85-54-0$ & $8.79 \mathrm{~b}$ & $3.55 \mathrm{a}$ & $6.75 \mathrm{ab}$ \\
$85-54-54$ & $6.56 \mathrm{a}$ & $3.38 \mathrm{a}$ & $7.06 \mathrm{ab}$ \\
$85-54-108$ & $7.43 \mathrm{ab}$ & $3.30 \mathrm{a}$ & $7.37 \mathrm{~b}$ \\
\hline
\end{tabular}

${ }^{2}$ Least-squares means.

y Mean separation was performed with the Bonferroni correction, $P<0.05 / 6$. LS means with different letters are significantly different. 
Table 3. Probabilities of significance in the ANOVA for the effects of soil, year, previous crop (prev), and planting vs. seeding (plan) on the brown bead incidence and severity, and the number of marketable broccoli heads for the four levels of $\mathrm{N}$ fertilization.

\begin{tabular}{|c|c|c|c|c|c|}
\hline & \multicolumn{4}{|c|}{$\mathrm{N}$ fertilization level } & \multirow{2}{*}{$\begin{array}{l}\text { All levels } \\
\text { combined }\end{array}$} \\
\hline & $85-0-0$ & $85-54-0$ & $85-54-54$ & $85-54-108$ & \\
\hline & \multicolumn{5}{|c|}{ Heads with brown bead (\%) } \\
\hline Soil (S) & 0.012 & 0.071 & 0.086 & 0.362 & 0.036 \\
\hline Year (Y) & 0.011 & 0.059 & 0.002 & 0.003 & 0.002 \\
\hline $\mathrm{Y} \times \mathrm{S}$ & 0.621 & 0.912 & 0.526 & 0.803 & 0.818 \\
\hline $\operatorname{Prev}(Y \times S)$ & 0.155 & 0.573 & 0.432 & 0.203 & 0.238 \\
\hline $\operatorname{Plan}(\mathrm{Y} \times \mathrm{S})$ & 0.778 & 0.336 & 0.456 & 0.182 & 0.431 \\
\hline \multicolumn{6}{|c|}{$L S$ means of soil series ${ }^{2}$} \\
\hline St-Blaise & $17.9 \mathrm{a}^{\mathrm{y}}$ & $14.6 \mathrm{a}$ & $11.3 \mathrm{a}$ & $9.0 \mathrm{a}$ & $13.3 \mathrm{a}$ \\
\hline Ste-Rosalie & $7.4 \mathrm{~b}$ & $7.4 \mathrm{a}$ & $5.9 \mathrm{a}$ & $6.4 \mathrm{a}$ & $6.7 \mathrm{~b}$ \\
\hline \multicolumn{6}{|c|}{ Severity index $(0-8)$} \\
\hline Soil & 0.352 & 0.572 & 0.894 & 0.024 & 0.580 \\
\hline Year & 0.012 & 0.464 & 0.223 & 0.091 & 0.033 \\
\hline $\mathrm{Y} \times \mathrm{S}$ & 0.168 & 0.262 & 0.534 & 0.144 & 0.234 \\
\hline $\operatorname{Prev}(\mathrm{Y} \times \mathrm{S})$ & 0.002 & 0.986 & 0.598 & 0.425 & 0.200 \\
\hline Plan $(Y \times S)$ & 0.560 & 0.212 & 0.199 & 0.352 & 0.342 \\
\hline \multicolumn{6}{|c|}{ LS means of soil series ${ }^{\mathrm{z}}$} \\
\hline St-Blaise & $3.93 \mathrm{a}$ & $3.44 \mathrm{a}$ & $3.53 \mathrm{a}$ & $3.92 \mathrm{a}$ & $3.70 \mathrm{a}$ \\
\hline \multirow[t]{2}{*}{ Ste-Rosalie } & $3.52 \mathrm{a}$ & $3.71 \mathrm{a}$ & $3.41 \mathrm{a}$ & $3.20 \mathrm{~b}$ & $3.46 \mathrm{a}$ \\
\hline & \multicolumn{5}{|c|}{ Marketable heads (no. $\left.m^{-2}\right)$} \\
\hline Soil & 0.768 & 0.801 & 0.761 & 0.788 & 0.804 \\
\hline Year & 0.485 & 0.141 & 0.016 & 0.012 & 0.082 \\
\hline $\mathrm{Y} \times \mathrm{S}$ & 0.086 & 0.013 & 0.004 & 0.001 & 0.006 \\
\hline $\operatorname{Prev}(\mathrm{Y} \times \mathrm{S})$ & 0.253 & 0.149 & 0.174 & 0.011 & 0.083 \\
\hline Plan $(\mathrm{Y} \times \mathrm{S})$ & 0.490 & 0.164 & 0.026 & 0.033 & 0.103 \\
\hline \multicolumn{6}{|c|}{ LS means of soil series ${ }^{2}$} \\
\hline St-Blaise & $6.14 \mathrm{a}$ & $6.72 \mathrm{a}$ & $7.07 \mathrm{a}$ & $7.50 \mathrm{a}$ & $6.86 \mathrm{a}$ \\
\hline Ste-Rosalie & $5.94 \mathrm{a}$ & $6.28 \mathrm{a}$ & $6.61 \mathrm{a}$ & $7.04 \mathrm{a}$ & $6.47 \mathrm{a}$ \\
\hline
\end{tabular}

${ }^{2}$ Least-squares means

${ }^{y} \mathrm{LS}$ means with different letters are significantly different, $P<0.05$.

There was generally no effect of the previous crop on the proportion of broccoli heads with brown bead or the severity of symptoms (Table 3). Only at a low level of $\mathrm{N}$ fertilization (i.e., 85-0-0) had the previous crop a significant effect on the severity of symptoms of brown bead. However, no consistent tendency was observed. In 1997, fields with corn or grain crops as previous crops had fewer symptoms than fields that had legumes (soybean or pea), whereas in 1998 and 1999, fields with corn as the previous crop had more symptoms than fields that had pea or grain crops (data not shown).

The ANOVA revealed no significant difference in brown bead incidence or severity between planted or direct-seeded broccoli (Table 3). However, at 85-54-54 and 85-54$108 \mathrm{~N}$ fertilization levels, direct-seeded fields had a higher number of marketable heads than transplanted fields. This may be partly due to the fact that direct-seeded fields had generally higher plant densities than transplanted fields.

This is the first report on decreased incidence of brown bead by increased $\mathrm{N}$ fertiliza- tion. The applications of 85-54-54 $\mathrm{N}$ are a standard fertilization practice for high-density plantings of broccoli. Growers should not fertilize at lower rates of $\mathrm{N}$ applications if they want to avoid the appearance of brown bead symptoms. Applying higher levels of N, such as $85-54-108$, will not decrease further the proportion of plants with brown bead. On the other hand, there is a risk of $\mathrm{N}$ leaching, which is likely to be harmful for the environment.

Despite the importance of rotations in broccoli production, the choice of the previous crop or whether the broccoli is seeded or transplanted had no detectable effect on brown bead appearance. The choice of the soil series, however, had an effect on brown bead incidence, especially at lower $\mathrm{N}$ fertilization levels. In this study, fields on the fine silt clay series of Saint Blaise had more heads with brown bead than fields on the clay series of Sainte Rosalie. In this particular case, the fields from the Sainte Rosalie series had been better supplied with fertilizer over the years than were fields from the Saint Blaise series, which was newly acquired land. Interestingly, as more $\mathrm{N}$ fertilization was supplied to the fields (i.e., from 85-0-0 to 85-54-108), the difference in occurrence of brown bead between the soil series became less important.

In this first study, we looked at the effects of basic management practices on brown bead appearance and severity. The next step is to investigate the relationships between brown bead and meteorological factors, such as temperature, relative humidity, solar radiation, and precipitation, along with soil and tissue nutritional factors. The results of that second study are presented in the companion paper.

\section{Literature Cited}

Conseil des Productions Végétales du Québec (CPVQ). 1995. Légumes: Crucifères (chou pommé, brocoli, chou-fleur et chou de Bruxelles). Feuillet technique du Conseil des Prod. Vég. du Québec. Agdex 252.

Flint, M.L. 1985. Integrated pest management for cole crops and lettuce. Univ. of California, Statewide Integrated Pest Mgt. Project, Div. Agr. Natl. Res., Oakland.

Grubbs, F.E. 1969. Procedures for detecting outlying observations in samples. Technometrics 11:1-21.

Hildebrand, P.D. 1994. Non-infectious diseases. In: R.J. Howard, J.A. Garland, and W.L. Seaman (eds.). Diseases and pests of vegetable crops in Canada. Can. Phytopathol. Soc. and Entomol. Soc. Can.

Lopez-Galarza, S., A. San Bautista, and J.V. Maroto. 1993. Influencia de la temperatura en la incidencia del desorden de Los Granos Marrones en broculi, cv 'Skiff'. Actas II Congr. lberico de Ciencias Hort. 1342-1345.

Maroto, J.V., S. Lopez-Galarza, B. Pascual, J. Alagarda, M.S. Bono. 1993. Influencia de dos sistemas de manejo forzado y de aplicaciones foliares càlcicas en el compotamiento productivo y la incidencia de la fisiopatatia de los "granos marrones" en los diversos cvs de Bròculi. Actas II Congr. lberico de Ciencias Hort. 1336-1341.

Pascual, B., J.V. Maroto, S. Lopez-Galarza, J. Alagarda, M.S. Bono, and A. San Bautista. 1996. Changes in some nutrient contents of broccoli (Brassica oleracea L. var. italica Plenck) inflorescences affected by the brown bud disorder. Acta Hort. 407:327-332.

SAS Institute. 1997. SAS for Windows, release 6.12. SAS Inst., Cary, N.C.

Sokal, R.R. and F.J. Rohlf. 1995. Biometry. 3rd ed. Freeman, New York

Steel, R.G.D., J.H. Torrie, and D.A. Dickey. 1997. Principles and procedures of statistics: A biometrical approach. 3rd ed. McGraw-Hill, New York.

Steta, M. 1987. Brown bead, a physiological disorder in broccoli (Brassica oleracea L. var. italica Plenck). MS, Univ. of California, Davis.

Tukey, J.W. 1977. Exploratory data analysis. Addison-Wesley, Reading, U.K. 